Marta PRZYSZYCHOWSKA

(Warszawa, UKSW)

\title{
NATURA LUDZKA JAKO ZAGUBIONA OWCA W NAUCZANIU OJCÓW KOŚCIOLA
}

Wydawać by się mogło, że przypowieść o zagubionej owcy (Mt 18, 12-14; Łk 15, 4-7) ma przede wszystkim na celu uzmysłowienie nam miłości Boga względem grzeszników i Jego pragnienia, by każdego z nich odzyskać. I taką interpretację Ojcowie Kościoła, oczywiście, znają i wykorzystują. Niemniej już bardzo wcześnie, bo w II wieku po Chrystusie, pojawiają się zupełnie inne wyjaśnienia obrazu błądzącej i odnalezionej owcy. Owcą jest nie tylko pojedynczy grzesznik, ale cała ludzka natura, która zbłądziła przez grzech, lecz została odnaleziona i odnowiona dzięki wcieleniu Syna Bożego. W Kościele starożytnym przekonanie o wspólnotowym wymiarze życia człowieka było czymś oczywistym, wypływającym zresztą z przekazu biblijnego ${ }^{1}$. Jednak niektórzy Ojcowie rozumieli tę wspólnotę o wiele głębiej - wyobrażali sobie ludzkość jako żywą, organiczną jedność. Taka koncepcja ludzkiej natury wypływa z jednej strony z charakterystycznego dla greckiego sposobu myślenia zainteresowania bardziej naturą niż jednostkami ${ }^{2}$, z drugiej zaś z przesiąknięcia filozofią, widocznego $\mathrm{w}$ teologii patrystycznej od samego jej początku. Koncepcja jedności ludzkiej natury została rozwinięta właśnie przez Ojców najbardziej zafascynowanych filozofią: Ireneusza z Lyonu, Metodego z Olimpu, Grzegorza z Nyssy. Oprócz wspomnianych pisarzy będę w tym artykule cytować jeszcze Orygenesa i Ambrożego, którzy stanowią przykład innej interpretacji przypowieści o owcy, jednak i oni mówią przy tej okazji o jedności ludzkiej natury. Każdy z nich rozumie tę jedność nieco inaczej, lecz w interpretacji zagubionej owcy mają punkty wspólne, które pozwalają na zestawienie ich wypowiedzi ze soba.

1. Owca to ludzka natura. Pierwszym, który w zagubionej owcy dostrzegł zabłąkaną ludzkość, był Ireneusz z Lyonu († ok. 202), gdy pisał:

\footnotetext{
${ }^{1}$ Por. H. Lassiat, Promotion de l'homme en Jésus-Christ d'après Irénée de Lyon témoin de la tradition des apôtres, Paris 1974, 261.

${ }^{2}$ Por. J. Daniélou, L'Apocatastase chez saint Grégoire de Nysse, RSR 30 (1940) 345.
} 
„Ręka Boga, która stworzyła nas na początku i stwarza w łonie matki, ta sama ręka w ostatnich czasach wyszukała nas zagubionych, odzyskała i wzięła na ramiona zagubioną owcę, i z radością przywróciła ją do stada życia"’3.

Odwołanie do przypowieści o owcy pojawia się u niego wielokrotnie, często jako część argumentacji, mającej przekonać czytelników, że Chrystus zbawia to samo stworzenie, które stworzył na samym początku - czyli Adama. Ireneusz podejmuje problem zbawienia pierwszego człowieka w związku z twierdzeniami Tacjana, że ludzie, owszem, zbawienia dostępują, ale nie Adam, który sprowadził na świat zło i grzech ${ }^{4}$. Ireneusz odpowiada:

„Łudzą się ci, którzy zaprzeczają zbawieniu Adama i sami siebie wykluczają z życia, bo nie wierza, że owca, która zaginęła, została odnaleziona. Jeśli bowiem nie została odnaleziona, to rodzaj ludzki do dziś trwa w zepsuciu"s.

$\mathrm{Z}$ jednej strony Ireneusz mówi tu wyraźnie o zbawieniu pierwszego człowieka, $\mathrm{z}$ drugiej jednak od razu utożsamia Adama z całym rodzajem ludzkim. Zdaje się, że tajemnica takiego utożsamienia tkwi w pojmowaniu przez Ireneusza ludzkości jako ontycznej, realnej jedności. Bardzo trudno jest ową jedność zdefiniować, ponieważ jest to jedno z założeń antropologicznych, których Ireneusz nigdzie nie wyjaśnia. W opracowaniach przeważa opinia, że jedność ta ma charakter mistyczny ${ }^{6}$. Nikt jednak nie pokusił się o bardziej szczegółowe wyjaśnienie, co taka mistyczna jedność miałaby oznaczać. Więcej uwagi zagadnieniu jedności ludzkiej natury u Ireneusza poświęcił jedynie H. Lassiat, uznając tę jedność za rzeczywistość ontyczną. Twierdzi on, że Bóg stworzył jednego człowieka, człowieka - ludzkość, by w swoim Synu umożliwić człowiekowi dostęp do niezniszczalności. Ten człowiek-ludzkość tworzy żyjącą i organiczną jedność, której pierwszy Adam był zarodkiem, a której głową ma być Chrystus, drugi Adam?7. Dodaje dalej: „Jedność ludzkości w dwu Adamach istnieje na płaszczyźnie fizycznej i duchowej oraz jest to jedność realna" (l'unité réelle $)^{8}$. Takie wyjaśnienie wydaje mi się bardziej przekonujące niż twierdze-

${ }^{3}$ Irenaeus, Adversus haereses V 15, 2, SCh 153, 206.

${ }^{4}$ Por. A. Orbe, Parabolas Evangelicas in San Ireneo, t. 2, Madrid 1972, 163-164.

${ }^{5}$ Irenaeus, Adversus haereses III 23, 8, SCh 211, 466.

${ }^{6}$ Por. A. Orbe, Antropologia de San Ireneo, Madrid 1969, 287; L. Scheffczyk, Urstand, Fall und Erbsünde: von der Schrift bis Augustinus, Freiburg 1981, 64; J.N.D. Kelly, Poczatki doktryny chrześcijańskiej, tłum. J. Mrukówna, Warszawa 1988, 133; J. Gross, Geschichte des Erbsündendogmas: ein Beitrag zur Geschichte des Problems vom Ursprung des Übels, Bd. 1: Entstehungsgeschichte des Erbsündendogmas. Von der Bibel bis Augustinus, München 1960, 92.

${ }^{7}$ Por. H. Lassiat, Création... Liberté... Incorruptibilité. Insertion du thème anthropologique de la jeune tradition Romaine dans l'oeuvre d'Irénée de Lyon, t. 2, Strasbourg 1971, 517.

${ }^{8}$ Tamże, s. 527. 
nia, że Adam jest symbolem ludzkości ${ }^{9}$ lub zawierał w sobie wszystkich ludzi ${ }^{10}$. Kolejnym krokiem w rozwoju myśli o jedności ludzkości w Adamie jest nauka Metodego z Olimpu (III w.). Komentatorzy są zgodni, że polemizując z Orygenesem oparł się na przemyśleniach Ireneusza ${ }^{11}$. On także w zagubionej owcy widzi jedną ludzką naturę.

„Słowo więc podniosło człowieka, aby po pokonaniu węża unieważnić wyrok potępienia wydany na skutek upadku. Wypadało bowiem, żeby zły duch został pokonany nie przez kogo innego, lecz przez tego właśnie, kogo oszukał, i chełpił się, że nad nim zapanował. Nie można byłoby inaczej rozbić grzechu i usunać potępienia, gdyby ten sam człowiek, któremu powiedziano: «Z ziemi powstałeś i do ziemi powrócisz», nie wznowił walki i nie unieważnił wyroku, z jego powodu wydanego na wszystkich; chodzi o to, aby - jak dawniej «W Adamie wszyscy umarli, tak teraz wszyscy zostali ożywieni w Chrystusie», który w Adama się przyodział"12.

Jak podkreśla L. Scheffczyk ${ }^{13}$, realizm Ireneusza został tu jeszcze zwielokrotniony: według Metodego Chrystus wcielając się przyjął zreanimowane ciało Adama:

„Adam był nie tylko symbolem i obrazem Chrystusa, ale Chrystus był rzeczywiście Adamem, ponieważ Słowo wstapiło w Niego przed wiekami. Wypadało bowiem, żeby pierworodna, pierwsza i jednorodzona latorośl Boga, Jego Mądrość, przybrała ciało połączywszy się z pierwszym człowiekiem, który był pierworodnym między ludźmi”'14.

A zatem owca, która się gubi i jest odnajdywana, to jedna ludzka natura, co więcej - ludzka natura obecna w Adamie jako pierwszym człowieku i jako przedstawicielu całej ludzkości.

Najbardziej rozwiniętą naukę o realnej jedności ludzkiej natury znajdujemy u Grzegorza z Nyssy († 394). W wielu swoich dziełach, zarówno dogmatycznych, jak i egzegetycznych mówi wprost:

„Jedna owca to jest nasza natura”"15; „to my, ludzie, jesteśmy ową zagubio-

${ }^{9}$ Por. D. Tum, Egzegeza przypowieści o zagubionej owcy (Lk 15, 4-7; Mt 18, 12-14) u Ireneusza i gnostyków, SACh 7 (1986) 187.

${ }^{10}$ Por. T. Dekert, Teoria rekapitulacji Ireneusza z Lyonu $w$ świetle starożytnych koncepcji na temat Adama, Kraków 2007, 38-39.

${ }^{11}$ Por. T. Badurina, Doctrina S. Methodii de Olympio de peccato originali et de eius effectibus, Romae 1942, 58-59; Gross, Geschichte des Erbsündendogmas, s. 111; Scheffczyk, Urstand, Fall und Erbsünde, s. 85.

${ }^{12}$ Methodius Olympius, Convivium decem virginum III 6, ed. H. Musurillo, SCh 95, Paris 1963, 102, tłum. S. Kalinkowski, ŹM 16, Kraków 1997, 153.

${ }^{13}$ Por. Scheffczyk, Urstand, Fall und Erbsünde, s. 85.

${ }^{14}$ Methodius Olympius, Convivium decem virginum III 4, SCh 95, 96-98, ŹM 16, 151.

${ }^{15}$ Gregorius Nyssenus, In Ecclesiasten hom. II, GNO 5, 305, tłum. M. Przyszychowska, ŹMT 51, Kraków 2009, 33. 
ną owca"”16; „to my, ludzka natura, będziemy tą owca, którą ocalił dobry pasterz" 17 ; ,jedna owca oznacza tu bowiem całą ludzką naturę"18.

Na czym polega owa jedność ludzkiej natury? Grzegorz jako jeden z niewielu Ojców zajął się tym zagadnieniem ${ }^{19}$ i stwierdził, że:

„natura jest jedna, tworząca sama ze sobąjedność i jest całkowicie niepodzielną monadą, nierosnącą przez dodanie ani niemalejącą przez ubytek, lecz jest w niej jedność i jako jedność pozostaje i ukazuje się w wielości, niepodzielna, trwała, nienaruszalna i nie dzieli się pomiędzy uczestniczących w niej”20.

Z takiej definicji natury wynikają niezwykle doniosłe dla historii człowieka konsekwencje: otóż zarówno upadek, jak i odkupienie, obejmą wszystkich, którzy w tej naturze mają udział.

Inaczej jedność ludzkości jako zabłąkanej owcy rozumiał wcześniej Orygenes († 254). Dla niego ta jedność ma jedynie wymiar mistyczny:

„Wszyscy bowiem jesteśmy jednym ciałem i jedną owcą. Jeden człowiek jest stopa, drugi głową, inny inną częścią ciała, Pasterz zaś, skoro przybył, zebrał «kość do kości i ścięgno do ścięgna» (Ez 37, 7-8), a zebrawszy wszystko w jedną całość zabrał ją do swego kraju. Jedność zaś powstaje na skutek miłości, prawdy i dobrego postanowienia, własnym więc słowem zjednoczył wszystkich"21.

Tutaj ludzkość nie jest realną, ontyczną jednością, ale jednością duchową, którą osiągamy dzięki łączności z Chrystusem. Podobnie na Zachodzie rozumie jedność ludzkości Ambroży († 397):

„Ta owieczka jest jedną nie w ogólnym, ale w szczegółowym znaczeniu, bo «wszyscy jesteśmy jednym ciałem» (1Kor 10,17), choć licznymi członkami, dlatego jest napisane: «Wy jesteście ciałem Chrystusa i członkami jego członków» (1Kor 12, 27). Przyszedł więc Syn Człowieczy, aby zbawić to, co było zginęło, albowiem «jak w Adamie wszyscy umierają, tak też w Chrystusie wszyscy odzyskują życie» (1Kor 15, 22). Bogaty więc pasterz, którego trzody my wszyscy jesteśmy setną częścią"22.

\footnotetext{
${ }^{16}$ Gregorius Nyssenus, Antirrheticus adversus Apollinarem, GNO 3/1, 152.

${ }^{17}$ Gregorius Nyssenus, Contra Eunomium III 2, 49, GNO 2, 68.

${ }^{18}$ Gregorius Nyssenus, In Canticum canticorum hom. II, GNO 6, 61, tłum. M. Przyszychowska, ŹMT 43, Kraków 2007, 47.

${ }^{19}$ Por. M. Przyszychowska, Nauka o tasce $w$ dziełach świętego Grzegorza z Nyssy, Kraków 2010, 17-48.

${ }^{20}$ Gregorius Nyssenus, Ad Ablabium quod non sint tres dei, GNO 3/1, 41, thum. T. Grodecki, ŹMT 21, 106.

${ }^{21}$ Origenes, Fragmenta in Lamentationes in catenis 28 (Jerem. 27, 17), GCS 6, 212, thum. S. Kalinkowski, PSP 30, Warszawa 1983, 226.

${ }^{22}$ Ambrosius, Expositio Evangelii secundum Lucam VII 209-210, ed. G. Tissot, SCh 52, Paris 1958, 87-88, thum. W. Szołdrski, PSP 16, Warszawa 1977, 336-337.
} 
2. Stado stworzeń rozumnych. Część z naszych Ojców Kościoła przywiązuje wielką wagę do symboliki stada stu owiec. Z cytowanych wyżej pisarzy temat ten w ogóle nie interesował jedynie Ireneusza. Nie pojawia się też u niego symbolizm liczby 99; ma ona jedynie ukazywać wielkość miłości Boga, który zostawia aż tyle owiec, by szukać jednej ${ }^{23}$. A. Orbe twierdzi także, że cohors (Adversus haereses V 15, 2), do której powraca owca, to nie aniołowie, ale raczej dom $\mathrm{Ojca}^{24}$.

Najwięcej miejsca symbolice setki poświęcił Orygenes. W Homiliach do Księgi Rodzaju podaje on następujące wyjaśnienie:

„«Trzysta», to trzy razy po sto; setka zaś jest liczbą pełną we wszystkim i doskonałą, bo zawiera w sobie tajemnicę całego rozumnego stworzenia, tak jak to czytamy w Ewangelii. Powiedziano tam: «Ten, kto ma sto owiec, a zgubi jedną z nich, pozostawia dziewięćdziesiąt dziewięć w górach i schodzi szukać tej, która zginęła; a gdy ją znajdzie, przynosi ją na swych ramionach i umieszcza razem z tymi dziewięćdziesięcioma dziewięcioma, które nie zginęły» (Mt 18, 12-13). Ponieważ zatem obejmująca całe rozumne stworzenie setka nie trwa sama z siebie, lecz pochodzi od Trójcy, a długość życia, to znaczy łaskę nieśmiertelności otrzymała od Ojca przez Syna i Ducha Świętego, przeto pomnożono ją przez trzy, jako taką, która przez łaskę Trójcy rośnie ku doskonałości i przez poznanie Trójcy przywraca do wartości trzystu to, co na skutek niewiedzy zniżyło się do setki" ${ }^{\prime 25}$.

Jak zauważa A. Orbe, poprzez tę przypowieść Orygenes ukazuje swoje ulubione idee: pierwotną równość stworzeń rozumnych przed ich zhierarchizowaniem w następstwie grzechu. Na początku panowała doskonała równość symbolizowana przez liczbę 100. Podczas gdy aniołowie zostali na wyżynach (w górach), człowiek upadł w materię ${ }^{26}$.

Dla pozostałych Ojców Kościoła stado stu owiec oznacza po prostu wspólnotę stworzeń rozumnych. Nie przywiązują oni wielkiego znaczenia do liczb, a mówią tylko o harmonii i wspólnocie ludzi z aniołami przed grzechem. Metody z Olimpu tak oto opisuje ów pierwotny stan:

„Pan, który na początku był u Boga i był Bogiem, był i jest naprawdę najwyższym Wodzem i Pasterzem bytów niebieskich, Jemu są posłuszne i idą za Nim wszystkie istoty rozumne, On nieprzerwanie pasie i przelicza gromady błogosławionych aniołów. Stała bowiem i doskonała jest liczba nieśmiertelnych żywych istot, podzielonych według rodów i gmin, odkąd człowiek zalicza się do tej gromady. A więc i człowiek został stworzony jako wolny od zagłady,

${ }^{23}$ Por. Orbe, Parabolas Evangelicas in San Ireneo, t. 2, s. 176.

${ }^{24}$ Por. tamże, s. 175.

${ }^{25}$ Origenes, In Genesim hom. 2, 5, SCh 7bis, 100, tłum. S. Kalinkowski, PSP 31/1, Warszawa $1983,47-48$

${ }^{26}$ Por. Orbe, Parabolas Evangelicas in San Ireneo, t. 2, s. 160. 
aby czcić Króla i Stwórcę wszechrzeczy, śpiewając dźwięczne pieśni wespół z rozlegającymi się z niebios głosami aniołów"27.

Podobnie Grzegorz z Nyssy uważa, że przed grzechem ludzka natura stanowiła jedność $\mathrm{z}$ aniołami:

„I my kiedyś stanowiliśmy pełną liczbę, bo i my zaliczaliśmy się do świętego grona stu rozumnych owiec"28.

Także Ambroży uważa ludzi za część stada aniołów - dlatego właśnie aniołowie cieszą się z odkupienia ludzkości:

„Bogaty więc pasterz, którego trzody my wszyscy jesteśmy setną częścią. Ma aniołów, ma archaniołów, panowania, potęgi, trony i innych niezliczone rzesze, które na górach pozostawił. Ponieważ są rozumne, nie bez podstawy cieszą się z odkupienia ludzi”29.

3. Grzech owcy - grzech natury? Najciekawsze i najtrudniejsze zarazem pytanie, jakie można postawić Ojcom, widzącym w owcy ludzką naturę, rozumianą jako ontyczna jedność, to pytanie o grzech, czyli zabłąkanie się owcy. Jeśli bowiem natura ludzka stanowi jedność, to grzech Adama nie tylko wpływa na wszystkich ludzi, ale w jakimś sensie wszyscy powinni mieć w nim udział. I rzeczywiście, już Ireneusz taki wniosek wyprowadza:

„A więc jak przez nieposłuszeństwo dziewicy człowiek upadł, a upadając umarł, tak przez dziewicę, która była posłuszna Słowu Bożemu, człowiek na powrót ożył i przyjął życie. Pan bowiem przyszedł szukać zagubionej owcy. A zagubił się człowiek. I dlatego nie powstało jakieś nowe stworzenie, ale rodząc się z tej, której ród był od Adama, zachował podobieństwo ukształtowania. Trzeba było bowiem zjednoczyć i streścić Adama w Chrystusa, aby to, co śmiertelne, wchłonięte zostało przez nieśmiertelność, a Ewa przez Maryje, aby dziewica stała się orędowniczką dziewicy i usunęła dziewicze nieposłuszeństwo przez posłuszeństwo dziewicy. To zaś przekroczenie, które zostało popełnione przy pomocy drzewa, zostało usunięte przez posłuszeństwo, przez które posłuszny Bogu Syn Człowieczy, przybity został gwoźdźmi do drzewa, odrzucając poznanie zła, a wprowadzając poznanie dobra. Złem jest nieposłuszeństwo Bogu, dobrem zaś posłuszeństwo Bogu"30.

Widać wyraźnie, że Ireneusz mówi o upadku Adama w perspektywie chrystologicznej. A. Orbe tłumaczy to tak: zarówno w złu, jak i w dobru, obowiązuje ta sama solidarność: jeśli obowiązywała w zgubie sprowadzonej przez prze-

${ }^{27}$ Methodius Olympius, Convivium decem virginum III 6, SCh 95, 100, ŹM 16, 152.

${ }^{28}$ Gregorius Nyssenus, In Ecclesiasten hom. II, GNO 5, 304-305, ŹMT 51, 33.

${ }^{29}$ Ambrosius, Expositio Evangelii secundum Lucam VII 210, SCh 52, 88, PSP 16, 336-337.

${ }^{30}$ Irenaeus, Demonstratio praedicationis apostolicae 33, SCh 406, Paris 1995, 128-130, thum. W. Myszor, ŹMT 7, Kraków 1997, 51-52. 
stępstwo stworzenia, musi obowiązywać też w triumfie zbawienia stworzenia $^{31}$. Zdaje się jednak, że Ireneusz wnioskuje raczej z końca o początku: nasze zbawienie w Chrystusie zależy od jedności Chrystusa z nami wszystkimi w Adamie A $^{32}$.

Z której by jednak strony nie patrzeć, efekt jest taki sam: dzięki realnej jedności ludzkiej natury cała ludzkość miała udział w grzechu Adama i ma udział w odkupieniu dokonanym przez Chrystusa. Najlepiej obrazuje to następujący wywód Ireneusza:

„Pan ukazał siebie i Ojca nie tylko przez to, co zostało przepowiedziane, lecz także przez samą mękę. Niszcząc to nieposłuszeństwo człowieka, które na początku dokonało się na drzewie, stał się posłusznym aż do śmierci i to śmierci na krzyżu, uzdrawiając dokonanym na drzewie posłuszeństwem nieposłuszeństwo, które zostało dokonane na drzewie. Nie przyszedłby zniszczyć przez to samo nieposłuszeństwa względem naszego Stwórcy, gdyby głosił innego Ojca. Lecz przez to właśnie, przez co nie usłuchaliśmy Boga i nie uwierzyliśmy Jego słowu, przez to samo wprowadził posłuszeństwo i uległość Jego słowu, przez to właśnie jawnie ukazał tego samego Boga, którego obraziliśmy w pierwszym Adamie (in primo Adam) przez niewypełnienie Jego przykazania; w drugim zaś Adamie zostaliśmy pojednani, bo staliśmy się posłuszni aż do śmierci. Staliśmy się dłużnikami nie kogo innego, lecz tego samego, którego przykazanie przekroczyliśmy na początku"33.

L. Scheffczyk słusznie podkreśla, że formuła „w Adamie” jest przez Ireneusza używana nie przypadkiem. Oznacza ona, że w pewnym sensie Adam jest tu całą ludzkością. W rozumieniu Ireneusza grzech Adama sam w sobie oraz związana z nią utrata szczęścia (zbawienia) musiały objąć całą ludzkość. A zatem osobisty grzech Adama stał się grzechem całej ludzkiej „natury”34.

Podobne rozumienie skutków grzechu Adama znajdujemy u Metodego z Olimpu. Pierwszy grzech zaszkodził nie tylko Adamowi, ale całemu rodzajowi ludzkiemu. Jak bowiem thumaczy T. Badurina, według Metodego wszyscy ludzie w jakimś sensie (sensu quodam) żyli w Adamie i uczestniczyli w jego przestępstwie. Dlatego sama ludzka natura została zraniona smutnymi skutkami pierwszego grzechu ${ }^{35}$ :

„Apostoł mówiąc: «Wiem bowiem, że we mnie, to znaczy w moim ciele, nie mieszka dobro» $(\mathrm{Rz} 7,18)$, chce wskazać na grzech, który od czasu [pierw-

\footnotetext{
${ }^{31}$ Por. Orbe, Antropologia de San Ireneo, s. 287.

${ }^{32}$ Por. Lassiat, Promotion de l'homme, s. 261.

${ }^{33}$ Irenaeus, Adversus haereses V 16, 3, SCh 153, 218-220.

${ }^{34}$ Por. Scheffczyk, Urstand, Fall und Erbsünde, s. 63.

${ }^{35}$ Por. Badurina, Doctrina S. Methodii de Olympio, s. 62.
} 
szego] występku zamieszkał w nas poprzez namiętności, a z którego jak nowe pędy i gałązki wyrastają myśli nieustannie szukające przyjemności"36.

I dla Grzegorza z Nyssy jest oczywiste, że jedność ludzkiej natury sprawia, iż wszyscy ludzie mają udział w grzechu Adama. Najwyraźniej mówi o tym nawołując wiernych do modlitwy o odpuszczenie grzechów:

„W tego rodzaju położeniu jak synowie marnotrawni po długiej, wśród wieprzów przeżywanej nędzy, kierujemy we łzach swe myśli ku niebieskiemu Ojcu, wołając do Niego: I odpuść nam nasze winy! Choćby kto był tak wielki jak Mojżesz, Samuel czy inny znany bohater cnoty, winien uważać tę prośbę za własna, bo każdy jest człowiekiem i uczestniczy w naturze Adama i jego wygnaniu. Ponieważ wszyscy - mówi Apostoł - umieramy w Adamie, dlatego też i dotyczące go słowa żalu odnoszą się również do nas, którzy z nim umarliśmy, abyśmy i my dostąpili przebaczenia grzechów i zbawili się w łasce Pana"37.

Jak widzimy, ludzie nie tylko obciążeni są skutkami pierwszego grzechu, ale wszyscy są za niego odpowiedzialni i obarczeni winą:

„Nasze życie zaczyna się w namiętności, w namiętności wzrastamy i w namiętności umieramy, zło jakby zmieszało się z naturą przez tych, którzy na początku ulegli namiętności i przez swoje nieposłuszeństwo nabawili się choroby. Jak natura żywych istot przechodzi zgodnie z rodzajem każdej na potomków i zgodnie z prawem natury potomek jest taki sam jak rodzic, tak samo z człowieka rodzi się człowiek, z poddanego namiętnościom im poddany, z grzesznika grzesznik. Grzech w jakiś sposób współistnieje z ludźmi, rodzi się z nimi, rośnie z nimi i kończy się wraz z ich życiem"38.

Grzegorz, mówiąc o grzechu, jaki dokonał się w raju, nie robi żadnej różnicy między Adamem i jego potomstwem. J. Gross thumaczy to jego przeświadczeniem, że natura ludzka ma swoją odrębną od jednostek realność (Gattungsrealismus): skutki grzechu dotykają całej ludzkiej natury, a zatem i wszystkich jednostek, którym jest wspólna ${ }^{39}$. Co więcej, J. Gaith nie waha się nazwać wypowiedzi Grzegorza potwierdzeniem nauki o grzechu pierworodnym w najbardziej klasycznym znaczeniu tego terminu ${ }^{40}$. A L. Scheffczyk dodaje, że tam, gdzie dominuje idea uniwersalnej ludzkiej natury, nie potrzeba schematu przekazywania grzechu dla stwierdzenia jego powszechności ${ }^{41}$.

\footnotetext{
${ }^{36}$ Methodius Olympius, De resurectione II 6, 4, ed. G.N. Bonwetsch, GCS 27, $200-201$.

${ }^{37}$ Gregorius Nyssenus, De oratione dominica hom. V, GNO 7/2, 66, thum. W. Kania, w: Modlitwa Pańska. Komentarze greckich Ojców Kościoła IV-V w., Kraków 1995, 75.

${ }^{38}$ Gregorius Nyssenus, De VIII beatitudinibus hom. VI, GNO 7/2, 145, thum. M. Przyszychowska, ŹMT 34, Kraków 2005, 81-82.

${ }^{39}$ Por. Gross, Geschichte des Erbsündendogmas, s. 153.

${ }^{40}$ Por. J. Gaith, La conception de la liberté chez Grégoire de Nysse, „Études de Philosophie Médiévale" 43 (1953) 112.

${ }^{41}$ Por. Scheffczyk, Urstand, Fall und Erbsünde, s. 149.
} 
Nie może dziwić fakt, że dla Orygenesa, który uważał wspólnotę ludzkości za jedność duchowa, nie ontyczną, upadek owcy oznacza zupełnie co innego. Interpretacje jego nauki utrudnia jego zwyczaj przytaczania kilku hipotez oraz głoszenia innej nauki dla wtajemniczonych, a innej dla prostaczków. Generalnie jednak Orygenes nie uznaje powszechności grzechu Adama, a jedynie powszechność jego skutków, przede wszystkim śmierci - chociaż wynika ona $\mathrm{z}$ powszechności zła ${ }^{42}$. Zło natomiast jest skutkiem wolnego wyboru każdego człowieka:

„A więc grzech zaczął królować na tym świecie od jednego Adama i królował nad tymi, którzy poszli za podobieństwem do grzechu Adama, i dlatego «grzech jednego przyniósł wyrok potępiający»" ${ }^{\text {"3 }}$.

Ambroży, jako jeden z nielicznych Ojców zachodnich bardzo wyraźnie podkreśla solidarność wszystkich ludzi z Adamem. Niekiedy jego wypowiedzi przypominają nawet cytowanych wyżej Ojców greckich:

„Był Adam, a w nim byliśmy wszyscy; zginął Adam, a w nim wszyscy zginęli’"44; „Upadłem w Adamie, z raju zostałem wyrzucony w Adamie, umarły w Adamie”"45; „Ostatecznie grzech pochodzi od Adama, od tego wina, od którego i Ewa pochodzi; od tego przewrotność, od którego pochodzi i rodzaj ludzki”4"

Zdaje się jednak, że podobieństwo jest jedynie pozorne. Jak widzieliśmy wyżej, Ambroży rozumie jedność ludzkiej natury inaczej niż Ireneusz, Metody i Grzegorz z Nyssy. Co więcej, sam wyznaje, że grzech Adama zranił naszą naturę, lecz:

„Inną jest nasza nieprawość, a inną pięty naszej, w którą zranił Adama ząb węża i pozostawił potomstwu prawem karnego dziedziczenia ranę, $\mathrm{z}$ powodu której kulejemy" ${ }^{\prime 7}$.

A zatem wykroczenie Adama, niesprawiedliwość pięty, którą zainfekowane dzieci Adama przychodzą na świat, nie jest grzechem jako takim, ale skłonnością do grzechu, czyli innymi słowy - złą namiętnością ${ }^{48}$.

${ }^{42}$ Por. Gross, Geschichte des Erbsündendogmas, s. 104-105; Scheffczyk, Urstand, Fall und Erbsünde, s. 81.

${ }^{43}$ Origenes, In Epistulam Pauli ad Romanos V 2, PG 14, 1026º, thum. S. Kalinkowski, PSP 57/1, Warszawa 1994, 269.

${ }^{44}$ Ambrosius, Expositio Evangelii secundum Lucam 7, 234, SCh 52, 96, PSP 16, 345.

${ }^{45}$ Ambrosius, De excessu fratris Satyri II 6, PL 16, 1374, thum. J. Czuj, POK 21, 141.

${ }^{46}$ Ambrosius, De Tobia 23, 88, CSEL 32/2, 570, thum. J. Jundziłł, PSP 35, Warszawa 1986, 118.

${ }^{47}$ Ambrosius, Expositio super Psalmum 48, 6, PL 14, 1357, thum. W. Eborowicz, w: Św. Augustyn, Przeciw Julianowi I 10, PSP 19/1, 87.

${ }^{48}$ Por. Gross, Geschichte des Erbsündendogmas, s. 242. 
4. Odnalezienie owcy: apokatastaza? Remedium na skażenie natury jest odkupienie. Jak cała natura miała udział w grzechu, tak samo cała ma udział w zbawczym dziele Chrystusa. Dla Ireneusza owo odnowienie natury przyjmuje postać rekapitulacji. Utarło się definiować rekapitulację, jako powtórzenie i odnowienie wszystkiego w Chrystusie ${ }^{49}$. Nie jest to jednak definicja precyzyjna. J. Vives skonfrontował taką wizję rekapitulacji z teorią Ireneusza o stworzeniu człowieka w stanie dziecka: Adam został mianowicie stworzony jako przeznaczony do rozwoju aż do pełnego posiadania Boga, lecz przez grzech utracił tę możliwość. Chrystus przyszedł, by odnowić nie stan pierwszego Adama, lecz jego cel, ku któremu człowiek ma zmierzać dzięki ewolucji/rozwojowi ${ }^{50}$. To bardzo istotne doprecyzowanie wyjaśnia, jak sądzę, dlaczego Ireneusz, mimo założeń, które powinny go prowadzić do teorii apokatastazy $^{51}$, nie dochodzi jednak do przekonania o powszechnym zbawieniu wszystkich ludzi (a tym bardziej szatana). Chociaż odkupienie w dużej mierze dokonuje się w samym akcie Wcielenia, jednak odnowienie ludzkiej natury nie oznacza odnowienia doskonałego obrazu Bożego, lecz umożliwienie dążenia ku temu celowi. Dlatego odnalezienie owcy, choć dotyczy całej ludzkiej natury jako jedności, jest dla Ireneusza dopiero pierwszym krokiem ku zbawieniu poszczególnych ludzi.

Podobną interpretację znajdziemy u Metodego z Olimpu. Uważa on mianowicie, że człowiek nie został stworzony jako doskonały, lecz miał zmierzać do doskonałości. Grzech przerwał ten proces, lecz wcielenie Słowa na nowo umożliwiło człowiekowi osiagnięcie podobieństwa do Boga:

„Pierwotnie człowiek nie był jeszcze doskonały, dlatego też nie miał sił, żeby się zbliżyć do doskonałości - do dziewictwa. Stworzony bowiem „na obraz” Boga musiał uzyskać jeszcze „podobieństwo” do Niego. Słowo, które zostało zesłane na ziemię, aby sprawę tę urzeczywistnić, przybrało najpierw ludzką postać, napiętnowaną wieloma grzechami. Chrystus dokonał tego w tym celu, abyśmy my, dla których przybrał ludzką postać, mogli z kolei przybrać postać Bożą. Wówczas wszak możemy stanowić dokładne podobieństwo Boga, gdy ucząc się iść po drodze, którą On objawił, w pełni wymodelujemy w sobie jak biegli malarze te same, co On, znamiona ludzkiego sposobu życia. W tym celu On, chociaż był Bogiem, postanowił odziać się w ludzkie ciało, abyśmy

${ }^{49}$ Por. A. d'Alés, La doctrine de la récapitulation chez St. Irénée, RSR 6 (1916) 189; E. Scharl, Der Rekapitulationsbegriff des hl. Irenäus und seine Anwendung auf die Körperwelt, OCP 6 (1940) 396; A. Benoît, Saint Irénée : introduction à l'étude de sa théologie, Paris 1960, 226; Kelly, Poczatki doktryny chrześcijańskiej, Warszawa 1988, 134; K. Leśniewski, Adam-Christ Typology in St. Irenaeus of Lyons, RT 41 (1994) z. 7, 64, przypis 7; Dekert, Teoria rekapitulacji Ireneusza z Lyonu, s. 38 .

${ }^{50}$ Por. J. Vives, Pecado original y progreso evolutivo del hombre en Ireneo, EE 43 (1968) 586-587.

${ }^{51}$ Por. D'Alés, La doctrine de la récapitulation chez St. Irénée, s. 199-200. 
widząc jak gdyby wymodelowany boski obraz, potrafili naśladować Twórcę tego wizerunku" 52 .

Inną wizję pierwotnego stanu człowieka, a co za tym idzie - również inną wizję jego odnowienia, miał Grzegorz z Nyssy. Wyszedł on mianowicie z założenia, że na początku historii ludzkości Bóg dokonał nie jednego, lecz dwóch aktów stworzenia. W pierwszym akcie stworzenia powstała ludzka natura rozumiana jako ontyczna jedność, doskonała i pozbawiona podziału na płcie. Przewidując grzech człowieka, Bóg dokonał drugiego stworzenia, w wyniku którego powstał pierwszy człowiek naznaczony płciowością ${ }^{53}$. Natomiast wszystkie cechy, które wiążemy z obecną kondycją ludzi, czyli cielesność w znanej nam postaci, są tak naprawdę cechami zwierzęcymi, dodanymi ludzkiej naturze po grzechu jako „ubrania ze skór" ${ }^{54}$. Jak grzech zepchnął człowieka na niższy, obcy ludzkiej naturze, poziom bytu, tak odkupienie przywraca mu utracony obraz Boży:

„Ostatecznym celem drogi jest powrót do początku, czyli upodobnienie się do Boga" $"$.

Dla Grzegorza przełomowym momentem w historii ludzkości jest wcielenie Syna Bożego:

„I my kiedyś stanowiliśmy pełną liczbę, bo i my zaliczaliśmy się do świętego grona stu rozumnych owiec, lecz kiedy jedna owca, to jest nasza natura, zabłądziła z dala od niebiańskiego sposobu życia ściąnnięta przez zło w dół do przykrego i brudnego miejsca, nie wspomina się już o takiej samej liczbie pozostałych owiec, lecz mówi się, że jest ich dziewięćdziesiąt dziewięć. Marność jest bowiem poza liczbą rzeczy istniejących i dlatego nie będzie można policzyć tego, czego nie ma. Przyszedł więc [Zbawiciel], by szukać i ocalić to, co zginęło, by wziąwszy na ramiona, przywrócić do [wspólnoty] istnień to, co zginęło przez marność [rzeczy] nieistniejących, aby liczba stworzenia Bożego była na powrót doskonała dzięki bezpiecznemu przyprowadzeniu tego, co zginęło, do tego, co nie ginie"

Z drugiej jednak strony, nie możemy zapominać o wyraźnych wypowiedziach Grzegorza na temat wiecznego piekła i potępienia. Szczególnie w homiliach dobitnie przedstawia wieczną karę potępionych:

„Każdemu dostaje się odpowiednia zapłata: tym, którzy prowadzili cnotli-

\footnotetext{
${ }^{52}$ Methodius Olympius, Convivium decem virginum I 4, SCh 95, 62-64, ŹM 16, 136.

${ }^{53}$ Por. Gregorius Nyssenus, De opificio hominis 16, SCh 6, 154.

${ }^{54}$ Por. Gregorius Nyssenus, Dialogus de anima et resurrectione, PG 46, 148.

${ }^{55}$ Gregorius Nyssenus, De mortuis non esse dolendum, GNO 9, 51 ; por. De virginitate 12, 4.

${ }^{56}$ Gregorius Nyssenus, In Ecclesiasten hom. II, GNO 5, 304-305, ŹMT 51, 33-34.
} 
we życie przypada radosny pobyt w królestwie niebieskim; nieludzkim zaś i złym - kara ogniowa i to na wieki" ${ }^{\prime 57}$.

Można powiedzieć, że chociaż Grzegorz wyraża pewne wątpliwości co do powrotu poszczególnych ludzi do stanu pierwotnej doskonałości, to zasadniczo, jak to słusznie zauważa J. Daniélou, „kładzie akcent jedynie na zbawienie ludzkiej natury, rozważanej jako cała ludzkość, a problem indywidualnego zbawienia pozostawia $\mathrm{w}$ cieniu. Widzimy tu dobrze grecki sposób myślenia, który interesuje się raczej naturą niż jednostkami" "58. Koncepcja apokatastazy Grzegorza z Nyssy stanowi zatem ukoronowanie idei jedności ludzkiej natury, charakterystycznej dla greckiej myśli filozoficznej, nie tylko chrześcijańskiej.

Apokatastaza w wersji Orygenesa to zupełnie inna koncepcja. Po pierwsze, jest to dla niego tylko hipoteza ${ }^{59}$. Po drugie, chociaż Orygenes przyjmuje możliwość powrotu wszystkich stworzeń do stanu pierwotnego, powrót ten nie ma związku z ideą jedności ludzkiej natury, lecz oparty jest na założeniu o skuteczności Boskiej pedagogii ${ }^{60}$. Także Ambroży nie wspomina o powrocie wszystkich do Boga, bo choć pozostawał pod wielkim wpływem myśli greckiej, był jednak człowiekiem Zachodu, gdzie na pierwszy plan wysuwano kwestie moralne, nie ontologiczne.

Najlepszym podsumowaniem rozważań Ojców Kościoła o zagubionej owcy jako grzeszącej i odkupionej ludzkiej naturze, może być wywód Ireneusza z Lyonu, w którym porównuje on uzdrowienie niewidomego do stworzenia człowieka:

„Gdy uczniowie Go pytali, dlaczego człowiek ten był ślepy od urodzenia, czy to była wina jego, czy jego rodziców, odpowiedział: «Nie zgrzeszył ani on, ani jego rodzice, lecz aby objawiły się w nim dzieła Boże» (J 9, 3). A dzieła Boże to stworzenie człowieka. Tak bowiem tego dokonał, jak to opisuje Pismo: «I wziął Bóg błoto z ziemi i stworzył człowieka» (Rdz 2, 7). Dlatego

${ }^{57}$ Gregorius Nyssenus, De beneficentia (De pauperibus amandis I), GNO 9, 100, thum. T. Sinko, w: Św. Grzegorz z Nyssy, Wybór pism, Warszawa 1963, 171; por. In illud: Quatenus uni ex his fecistis mihi fecistis (De pauperibus amandis II), GNO 9, 121; In inscriptiones Psalmorum II 16, GNO 5,172 .

${ }^{58}$ Daniélou, L'Apocatastase chez saint Grégoire de Nysse, s. 345.

${ }^{59}$ Sam Orygenes oburzał się, że ktoś mógłby go posądzać o tak niedorzeczną koncepcję (Epistula ad quosdam caros suos Alexandriam, CCL 20, 11, 4-11, thum. H. Pietras: List do przyjaciót w Aleksandrii, w: Orygenes, Korespondencja, ŹMT 6, Kraków 1997, 26): „Niektórzy z tych, którzy chętnie oczerniają swoich bliźnich, mnie i mojej nauce przypisują zbrodnię bluźnierstwa, czego ode mnie nigdy nie słyszeli. Powiadają że moim zdaniem ojciec zła i zguby tych, których się wyrzuca z królestwa Bożego, czyli diabeł, będzie zbawiony; czego nawet ktoś puknięty w głowę i wyraźnie nierozumny powiedzieć nie może”.

${ }^{60}$ Por. Origenes, De principiis III 6, 5-6. 
i Pan splunął na ziemię i uczynił błoto, i nałożył je na oczy $(\mathrm{J}$ 9, 6), ukazując, w jaki sposób powstało dawne stworzenie (antiquam plasmationem) i tym, którzy mogli zrozumieć objawił rękę Boga, którą człowiek został stworzony z błota. To, co Słowo-twórca pominęło w łonie matki, jawnie dopełniło, aby objawiły się w nim dzieła Boże i byśmy nie szukali innej ręki, która stworzyła człowieka ani innego Ojca, wiedząc, że ręka Boga, która stworzyła nas na początku i stwarza w łonie matki, ta sama ręka w ostatnich czasach wyszukała nas zagubionych, odzyskała i wzięła na ramiona zagubioną owcę, i z radością przywróciła ją do stada życia"'61.

\section{HUMAN NATURE AS THE LOST SHEEP ACCORDING TO THE FATHERS OF THE CHURCH}

(Summary)

It may seem that the main goal of the parable of the lost sheep (Mt 18, 12-14; Lk 15, 4-7) is to make us aware how much God loves sinners and how deeply He wants to regain them. The Fathers of the Church, of course, knew that kind of interpretation, nevertheless very early in history they started to apply a completely different explanation to the lost and found sheep. Already in the 2 nd century we can find the statement that the sheep is not a single sinner but the entire human nature, which got lost through the original sin committed by Adam and was found and renewed thanks to the incarnation of God's Son. In the Antiquity, it was universally believed that human life had a common dimension. That belief was a great part of ancient philosophy as well as the biblical tradition. Some of the Fathers understood the communion even deeper than others as they imagined the humanity as a living organic entity. The concept of the ontological unity of human nature was developed mostly by three Fathers: Irenaeus (2nd century), Methodius of Olympus (died c. 311) and Gregory of Nyssa (died c. 394). All three of them used the parable of the lost sheep as an example that could explain this doctrine. Besides, two more Fathers, Origen and Ambrose of Milan, spoke about the unity of the humanity when they explained the parable of the lost sheep, though their interpretation of this unity is completely different. However all five Fathers have something in common, which allows me to compare their deliberations on the parable together.

\footnotetext{
${ }^{61}$ Irenaeus, Adversus haereses V 15, 2, SCh 153, 204-206.
} 
